\title{
Uyarlanmış Yüzme Eğitiminin, Özel Gereksinimli Çocuklar Üzerindeki Etkilerinin Ebeveynleri Tarafından Seslendirilmesi
}

\author{
Yeşim ALBAYRAK KURUOĞLU ${ }^{1 *}$, Dilek UZUNÇAYIR²
}

\author{
${ }^{1}$ Haliç Üniversitesi, Beden Eğitimi ve Spor Y.O., İstanbul. https://orcid.org/0000-0002-6684-122X \\ ${ }^{2}$ Gazi Üniversitesi, Sağlik Bilimleri Enstitüsü, Beden Eğitimi ve Spor A.B.D. Ankara. \\ https://orcid.org/0000-0003-2678-0255
}

\section{Orijinal Makale}

Gönderi Tarihi: 16.11.2020
Kabul Tarihi: 24.12.2020
DOI: $10.30769 /$ usbd. 826474

Online Yayın Tarihi: 31.12.2020

\section{$\ddot{O} \mathbf{z}$}

$\mathrm{Bu}$ araştırma, sosyal yapılandırmacı paradigmaya göre, İstanbul'daki bir belediye havuzunda özel gereksinimli çocuklara yönelik düzenlenen 14 haftalık uyarlanmış yüzme eğitiminin etkilerini, onların ebeveynleri tarafindan dile getirilmesi üzerine kurgulanmışır. Araştırmada, özel gereksinimli çocuklarının yaşadıkları deneyimler, ebeveynlerin bakış açısıyla seslendirilerek sübjektif anlamlara ulaşılmaya çalışılmıştır. Çalışma grubunu, İstanbul'da Avrupa yakasında yer alan bir belediye havuzunda 14 hafta süresince, haftada 2 gün, günde 60 dakika uyarlanmış yüzme eğitimine düzenli devam eden 20 özel gereksinimli çocuğun ebeveynleri arasından, gönüllü olarak görüşmeyi kabul eden 10 ebeveyn(anne) oluşturmuştur. Yarı yapılandırılmış görüşme formu düzenlenerek sorulan sorular, araştırmaya katılan ebeveynlerin izni ile ses kayıt cihazına kaydedilmiştir. Daha sonra düz metine çevrilen görüşmeler, içerik analizi yöntemiyle çözümlenerek ana kategorilere ve bu kategoriler altında ortaklaşan kodlara ulaşılmıştır. Araştırmadan elde edilen kategoriler sırasıyla "yönlendiren kişiler", "hareketsizlik nedeni", "motivasyon", "fiziksel katkı", "zihinsel katkı", "sosyal katkı" ve "davranışsal katkı" olarak belirlenmiştir. Belirlenen kategorilerden, toplamda 20 kod elde edilmiştir. Araştırma sonucunda ebeveynler, uyarlanmış yüzme eğitimine düzenli katılan çocuklarda genellikle olumlu değişimler gözlediklerini belirtmişlerdir. Ebeveynlerin ifadelerinden elde edilen veriler, belediye hizmeti olan uyarlanmış yüzme eğitimi sonucunda gözlenen fiziksel ve sosyal katkı frekans sayılarının diğer kategorilere göre daha yüksek olduğunu göstermektedir. Özel gereksinimli çocukların hareketsizlik nedenlerinin ortaya çıkarılarak, aktivite düzeylerinin arttırılmasına yönelik belediyeler tarafindan sunulan bu tür hizmetler, onların temel hareket becerilerine ve genel vücut sağlığına faydalı olabilir, bununla birlikte toplumla bütünleşmeleri için imkan yaratabilir. Nitel araștırma yöntemiyle gerçekleştirilen bu araştırma, toplumda "dezavantajlı gruplar" içinde yer alan özel gereksinimli çocukların seslerini, ebeveynleri aracılığıla duyulmasına imkan tanıyabilir.

Anahtar kelimeler: Uyarlanmış yüzme, özel gereksinimli çocuk, ebeveyn, nitel araştırma.

\section{Statements of Parents About the Impact of Adapted Swimming Education on Children with Special Needs}

\begin{abstract}
This research was set up according to the social constructivist paradigm. It was aimed to explain the statements of parents whose children participated in 14 weeks of adapted swimming program in a municipal pool in Istanbul. In the study, the experiences of children with special needs were voiced by their parents and subjective meanings were tried to be reached. The working group consisted of 10 parents(mothers) who voluntarily participated in the research among 20 parents. Their children with special needs were regularly attending adapted swimming program for 60 minutes a day, 2 days a week, at a municipal pool on the European side in Istanbul for 14 weeks. A semi-structured interview form was arranged and all the interviews were recorded with the permission of the attendant parents. Then the interviews were translated into a plain text. Transcripts were analysed by content analysis method and the main categories and codes were reached. The categories obtained from the research were "guiding persons", "cause of inactivity", "motivation", "physical gains", "mental gains", "social gains" and "behaviour changes" respectively. A total of 20 codes were obtained from the specified categories. As a result of the research, parents noted that they observed positive changes in children who regularly participated in adapted swimming program. Parents' statements showed that frequency numbers of physical and social gains are higher than in other categories. Such services offered by municipalities to increase activity levels by identifying the causes of inactivity of children with special needs can be beneficial to their basic mobility skills and general body health, as well as they create opportunities for them to integrate with society. This qualitative research holds the potential of allowing the voices of children with special needs to be heard through their parents' statements. Keywords: Adapted swimming, child with special needs, parent, qualitative research.
\end{abstract}

\footnotetext{
* Sorumlu Yazar: Yeşim ALBAYRAK KURUOĞLU, Eposta: yesimkuruoglu@ halic.edu.tr
} 


\section{GíRiş}

Uyarlanmış yüzme eğitimi, özel gereksinimli çocuklar için en çok tercih edilen, eğlendirici, motivasyon arttırıcı ve tercih edilen terapötik fiziksel aktiviteler içinde yer almaktadır (Getz, Hutzler ve Vermeer, 2007). Havuz ortamında ve suda gerçekleştirilen aktiviteler, düşük egzersiz motivasyonu olan tüm çocuklar tarafindan sevilmektedir (Albert 2010). Örneğin, daha önce yüzme eğitimi almamış olan otizm spektrum bozukluğuna sahip çocukların, uyarlanmış yüzme eğitimi programıla yüzme becerilerinin geliştiği ve \%74'nün belirli bir yüzme seviyesine ulaştığ gözlenmiş̧tir (Lawson, Foster ve Harrington, 2014).

Suyla direkt temas halinde olan çocuklar, su içindeki hareket becerilerini geliştirerek, daha karmaşık su içi egzersizlerini ve temel yüzme becerilerini sergileyebilir düzeye ulaşabilmektedir. Uyarlanmış yüzme eğitimi, özel gereksinimli çocukların temel hareket becerilerini geliştirerek, motor beceri gelişimlerini desteklemektedir (Martin,1983; Miller, 2005). Fragala-Pinkham, Haley ve O'Neil (2011), 14 hafta süreyle uyarlanmış su içi egzersizlerine katılan otizm spektrum bozukluğu olan çocukların kardiyovasküler kapasiteleri, temel hareket becerileri ve temel yüzme becerilerinin geliştiğini gözlemlemişlerdir. Casey, Rasmussen, Mackenzie ve Glenn (2010) ise, zihinsel yetersizliği olan çocuklarda ve adölesanlarda, 16 haftalık uyarlanmış yüzme eğitim programının fiziksel uygunluğu ve vücut kompozisyonu üzerinde olumlu etkileri olduğunu saptamışlardır. Çamlıgüney (2001), 3 aylık kara egzersizleri ve uyarlanmış yüzme eğitiminin, Down sendromlu çocuklar üzerindeki etkilerini karşılaşıırmış, uyarlanmış yüzme grubundaki çocukların fiziksel kapasitelerinde daha fazla gelişme gözlemiştir.

Havuz ortamının motive edici etkisi, tüm çocuklarda motor becerilerin yanında, grup çalı̧̧malarına katılmış olma neticesinde özgüven, farkındalık ve sosyal yaşam becerilerinin gelişimini desteklemektedir (Martin,1983; Miller, 2005). Pan (2010), su içi egzersizlere düzenli devam eden özel gereksinimli çocukların sosyal etkileşimlerinde ve davranışlarında pozitif gelişmeler olduğunu kaydetmiş̧tir. Yılmaz, Yanardağ, Birkan ve Bumin (2004), 10 hafta uygulanan su içi egzersizlerin, kendi etrafında dönme, olduğu yerde sallanma gibi stereotipik davranışların kontrol altına alınıp, azalmasına yardımcı olduğunu belirtmişlerdir. Albayrak Kuruoğlu ve Uzunçayır (2020), 14 haftalık su içi egzersizlerin zihinsel yetersizliğe sahip çocukların sosyal beceri gelişimine katkı sağladığı sonucuna ulaşmışlardır. Ayrıca, su içerisindeki oyun becerilerinin çok sayıda özel gereksinimli çocuğa potansiyel öğrenme firsatı sunabileceği belirtilmektedir (Yllmaz, Konukman, Birkan ve Yanardağ, 2010). FragalaPinkham, O'Neil ve Haley (2010), 14 hafta süreyle su içinde basketbol gibi çeşitli oyunlara katılan özel gereksinimli çocukların ebeveynleriyle yaptıkları bir çalı̧̧ada, ebeveynler program sona erdikten sonra dahi çocuklarının günlük yaşam becerilerinde elde ettikleri kazançların devam ettiğini ifade etmişlerdir.

Özel gereksinimli çocuklar, zamanlarının çoğunu okul ve özel eğitim merkezleri gibi ortamlarda geçirirken, spor salonu veya havuz gibi kalabalık sosyal çevrelerden yeterince yararlanamazlarsa topluma uyum sorunları yaşayabilmektedirler. Havuzda gerçekleştirilen aktiviteler, özel gereksinimli çocuklara temel hareket becerileri kazandırarak, okul dışında farklı bir sosyal çevrede akademik becerilerle sınırlı olan öğrenimi sosyal becerilerle 
genişletme imkanı sunabilir (Yılmaz, Konukman, Birkan ve Yanardağ, 2010; Albayrak Kuruoğlu ve Uzunçayır, 2020).

İstanbul'da bir belediye hizmeti olarak 14 hafta süresince, haftada 2 gün, günde 60 dakika uyarlanmış yüzme eğitiminden yararlanan özel gereksinimli çocukların ebeveynleri, bu eğitimin çocukları üzerinde yarattığı etkileri kendi ifadeleriyle dile getirmişlerdir. $\mathrm{Bu}$ çalışmanın amacı, ebeveynlerin dile getirtiği konuları derinlemesine inceleyerek, sübjektif anlamlara ulaşmaktır.

\section{YÖNTEM}

\section{Araştırma Modeli}

$\mathrm{Bu}$ araştırma, sosyal yapılandırmacı paradigmaya (social constructivist paradigm) göre, nitel araştırma yöntemleri içerisinde yer alan fenomenoloji (olgu bilim) deseniyle kurgulanmıştır. $\mathrm{Bu}$ bakış açısında insanların yaşam deneyimleri ve görüşlerinden yola çıkarak, belirli kuram ya da anlamlara varılmak istenir (Creswell, 2013). Araştırmada, 14 hafta süreyle uyarlanmış yüzme eğitimine katılan özel gereksinimli çocukların yaşadıkları deneyimler, ebeveynlerinin bakış açısıyla dile getirilerek, sübjektif anlamlara ulaşılmaya çalışılmıştır.

\section{Çalışma Grubu}

$\mathrm{Bu}$ araştırmada, nitel araştırmalarda kullanılan amaçlı örnekleme yöntemlerinden ölçüt örnekleme kullanılmıştır. Ölçüt örneklemede, önceden belirlenen bir dizi ölçütü karşılayan bütün durumlar çalışılır (Patton, 2014). Bu araştırmaya katılma ölçütü, İstanbul ilinde yerel yönetime ait bir havuzda 14 hafta boyunca, haftada 2 gün, günde 60 dakika olarak programlanan uyarlanmış yüzme eğitimine ilk defa katılan 20 özel gereksinimli çocuğun ebeveyni olmaktır. 20 ebeveyn içinde ise, yüz yüze görüşmeyi kabul eden 10 ebeveyn araştırmanın katılımcılarını oluşturmuştur. Araştırmaya gönüllü katılan ebeveynlerin hepsi de, özel çocukların anneleridir. Araştırmaya katılan anneler, "A" olarak isimlendirilmiş, kişi isimleri gizlenerek katılımcılara numara verilmiş “A1, A2, A3.." şeklinde kodlanmıştır.

Araştırmaya katılan ebeveynler ve çocukları hakkındaki sosyo-demografik bilgiler Tablo 1'de belirtilmiştir.

Tablo 1. Araştırmaya katılan ebeveynler ve çocuklarının sosyo-demografik bilgileri

\begin{tabular}{|c|c|c|c|c|c|c|}
\hline $\begin{array}{l}\text { Katılımcı } \\
\text { Kodu }\end{array}$ & $\begin{array}{l}\text { Görüşülen } \\
\text { Ebeveyn }\end{array}$ & $\begin{array}{c}\text { Annenin } \\
\text { Yaşı }\end{array}$ & $\begin{array}{c}\text { Eğitim } \\
\text { Durumu }\end{array}$ & $\begin{array}{c}\text { Ekonomik } \\
\text { Durumu }\end{array}$ & $\begin{array}{l}\text { Çocuğun } \\
\text { Yaşı }\end{array}$ & Çocuğun Tanısı \\
\hline A1 & Anne & 37 & İlkokul & Çalışmıyor & 7 & Hafif Zihinsel Yetersizlik \\
\hline A2 & Anne & 33 & İlkokul & Çalışmiyor & 7 & Otizm Spektrum Bozukluğu \\
\hline A3 & Anne & 49 & İlkokul & Çalışmıyor & 7 & Down Sendromu \\
\hline A4 & Anne & 37 & İlkokul & Çalışmiyor & 9 & Down Sendromu \\
\hline A5 & Anne & 37 & İlkokul & Çalışmiyor & 9 & Hafif Zihinsel Yetersizlik \\
\hline A6 & Anne & 41 & İlkokul & Çalışmiyor & 10 & Hafif Zihinsel Yetersizlik \\
\hline A7 & Anne & 37 & İlkokul & Çalışmiyor & 10 & Down Sendromu \\
\hline A8 & Anne & 34 & İlkokul & Çalışmiyor & 11 & Hafif Zihinsel Yetersizlik \\
\hline A9 & Anne & 43 & İlkokul & Çalışmiyor & 12 & Otizm Spektrum Bozukluğu \\
\hline A10 & Anne & 36 & İlkokul & Çalışmiyor & 12 & Hafif Zihinsel Yetersizlik \\
\hline
\end{tabular}


Programa katılan çocukların, uyarlanmış yüzme eğitimi dışında başka hiçbir spor branşında eğitim almadıkları ebeveynleri tarafından bildirilmiştir.

\section{Veri Toplama Aracı}

Uyarlanmış yüzme eğitimine katılan özel gereksinimli çocukların ebeveynlerinin programla ilgili görüşleri ve çocuklarına yaptığı katkılar hakkında derinlemesine bir araştırma yapabilmek için, yarı yapılandırılmış görüşme formu daha önce özel gereksinimli bireylerle çalışmalar yapmış olan araştırmacılar tarafından hazırlanmış ve yüz yüze görüşmeler yoluyla veri toplanmıştır (Merriam, 2013). Bu görüşme tekniğinde, araştırmacı görüşmenin akışına göre, ilave sorular ekleyebilmekte ve alınan cevapların ayrıntılı şekilde açıklanmasını sağlayabilmektedir. Bununla birlikte, bazı soruların cevapları başka sorularda alındıysa, tekrar aynı soruyu sormayabilir (Türnüklü, 2000).

Araştırmacıların hazırladığı yarı yapılandırlmış görüşme formu, "Ebeveynlerin özel gereksinimli çocuklarını uyarlanmış yüzme eğitimi programına katılmalarını desteklemesinde etkili olan faktörler nelerdir?”; "Uyarlanmış yüzme ĕgitimi programına katılan özel gereksinimli çocukların, ebeveynlerinin bakış açısıyla günlük yaşamlarında elde ettiği kazanımlar nelerdir?" rehber soruları yardımıyla oluşturulmuştur. Özel gereksinimli çocukların ebeveynleriyle yüz yüze 25-45 dakika süren görüşmeler, programın düzenlendiği İstanbul'da Avrupa yakasında bulunan bir belediyenin yüzme havuzunda gerçekleştirilmiştir. Görüşmeler sırasında, katılımcılardan izin alınarak ses kaydı alınmıştır.

Araştırmaya katılan ebeveynlere, aşağıdaki konular hakkında sorular yöneltilmiştir:

\section{-Uyarlanmış Yüzme Eğitimine Yönlendirmeye Karar Verme}

Çocuğunuzu yüzme branşına yönlendirme neden/leriniz nelerdir?

Çocuğunuzu yüzme branşına kim/ler veya hangi faktör/ler yönlendirdi?

\section{-Uyarlanmış Yüzme Eğitiminin Katkıları}

Çocuğunuzun yüzme eğitimi sürecinde, başlangıçtan bugüne kadar katılım istekliliği hakkında bilgi verir misiniz? Motivasyonu hakkında bir değişim gözlediniz mi?

Yüzme eğitimi çocuğunuzda fiziksel, zihinsel, sosyal becerilerinde ve davranışlarında değişiklik yarattı mı? Bu eğitimin çocuğunuza katkıları oldu mu? Olduysa bunlar nelerdir?

Bununla birlikte, katılımcıların sosyo-demografik özelliklerini belirlemeye yönelik soruların yer aldığı "Kişisel Bilgi Formu” ve etik kurallar çerçevesinde araştırmanın amacı ile verilerin ne şekilde kullanılacağını belirten "Bilgilendirme ve Onam Formu” imzalamaları istenmiştir.

\section{Verilerin Analizi}

Bu araştırmada, yüz yüze ve ses kaydı ile yapılan görüşmeler, öncelikle düz metine çevrilmiştir. Araştırmacılar, açık kodlama (open coding) yoluyla, düz metin verileri içindeki kategorileri veya temaları oluşturacak ortaklaşmaları keşfedebilmek için metinleri bir kereden daha fazla okumuş, benzerlik ve karşılaştırmaları ortaya çıkarmaya çalışmışlardır (Strauss ve Corbin, 1990). Son basamak olarak içerik analizi yöntemiyle verilerin analizi yapılmıştır. 
İçerik analizi yapmak için temalara ve betimsel analize ihtiyaç duyulur. İçerik analizi, ulaşılan temaların kapsamlı, derin ve karmaşık hali olarak açıklanabilir (Patton, 2014).

\section{BULGULAR}

Araştırmada 14 haftalık uyarlanmış yüzme eğitimine katılan özel çocukların ebeveynleriyle yapılan görüşmelerden elde edilen verilerin analizi sonucunda ulaşılan kategoriler (tema), kodlar (alt-tema) ve ilgili kodların tekrarlanma sıklığını ifade eden frekans değerleri Tablo 2'de verilmiştir.

Tablo 2. Uyarlanmış Yüzme Eğitiminin Özel Çocuklar Üzerindeki Etkileri İle İlgili Kategoriler, Kodlar ve Frekans Değerleri

\begin{tabular}{|c|c|c|c|}
\hline Kategoriler & Kodlar & $\begin{array}{c}\text { Katılımcilar } \\
(\mathbf{n}=\mathbf{1 0})\end{array}$ & Frekans \\
\hline \multirow{3}{*}{$\begin{array}{c}\text { Yönlendiren Kişiler } \\
f(10)\end{array}$} & Doktor Yönlendirmesi & $\mathrm{A} 3, \mathrm{~A} 10$ & $f(2)$ \\
\hline & Ebeveyn Yönlendirmesi & $\begin{array}{l}\mathrm{A} 1, \mathrm{~A} 4, \mathrm{~A} 5, \mathrm{~A} 6, \mathrm{~A} 7, \mathrm{~A} 8, \\
\mathrm{~A} 9\end{array}$ & $f(7)$ \\
\hline & Arkadaş Tavsiyesi & $\mathrm{A} 2$ & $f(1)$ \\
\hline \multirow[b]{2}{*}{$\begin{array}{c}\text { Hareketsizlik Nedeni } \\
\qquad f(7)\end{array}$} & Televizyon İzlemek & A2, A6 & $f(2)$ \\
\hline & $\begin{array}{l}\text { Bilgisayar/Telefon/Tablette } \\
\text { Oyun Oynamak }\end{array}$ & $\mathrm{A} 2, \mathrm{~A} 4, \mathrm{~A} 8, \mathrm{~A} 9, \mathrm{~A} 10$ & $f(5)$ \\
\hline \multirow{2}{*}{$\begin{array}{c}\text { Motivasyon } \\
f(10)\end{array}$} & İstekli Olmak & $\mathrm{A} 1, \mathrm{~A} 2, \mathrm{~A} 3, \mathrm{~A} 4, \mathrm{~A} 8, \mathrm{~A} 10$ & $f(6)$ \\
\hline & Mutlu Olmak & $\mathrm{A} 5, \mathrm{~A} 7, \mathrm{~A} 9, \mathrm{~A} 10$ & $f(4)$ \\
\hline \multirow{4}{*}{$\begin{array}{l}\text { Fiziksel Katkı } \\
f(16)\end{array}$} & Vücut Kompozisyonu & $\mathrm{A} 1, \mathrm{~A} 3, \mathrm{~A} 5, \mathrm{~A} 7, \mathrm{~A} 9$ & $f(5)$ \\
\hline & Hareket Becerileri & A2, A6 & $f(2)$ \\
\hline & Kaba Motor Beceriler & $\mathrm{A} 3, \mathrm{~A} 4, \mathrm{~A} 5, \mathrm{~A} 6, \mathrm{~A} 8$ & $f(5)$ \\
\hline & İnce Motor Beceriler & $\mathrm{A} 3, \mathrm{~A} 5, \mathrm{~A} 6, \mathrm{~A} 8$ & $f(4)$ \\
\hline \multirow{2}{*}{$\begin{array}{c}\text { Zihinsel Katkı } \\
f(8)\end{array}$} & Algıda Artış & $\mathrm{A} 1, \mathrm{~A} 5, \mathrm{~A} 7, \mathrm{~A} 9$ & $f(4)$ \\
\hline & Söyleneni Anlama & $\mathrm{A} 1, \mathrm{~A} 2, \mathrm{~A} 4, \mathrm{~A} 10$ & $f(4)$ \\
\hline \multirow{4}{*}{$\begin{array}{l}\text { Sosyal Katkı } \\
\qquad f(8)\end{array}$} & Genel iletişim & $\mathrm{A} 2, \mathrm{~A} 5, \mathrm{~A} 6, \mathrm{~A} 9$ & $f(4)$ \\
\hline & Konuşarak iletişim & A5 & $f(1)$ \\
\hline & İfade şekli & $\mathrm{A} 2, \mathrm{~A} 3$ & $f(2)$ \\
\hline & Vücut dilini kullanma & A9 & $f(1)$ \\
\hline \multirow{3}{*}{$\begin{array}{c}\text { Davranışsal Katkı } \\
f(13)\end{array}$} & Sakin Olmak & $\mathrm{A} 1, \mathrm{~A} 4, \mathrm{~A} 5, \mathrm{~A} 7, \mathrm{~A} 8, \mathrm{~A} 10$ & $f(6)$ \\
\hline & Özgüven & A5, A6, A7 & $f(3)$ \\
\hline & $\begin{array}{l}\text { Saldırgan Davranışlarda } \\
\text { Azalma }\end{array}$ & $\mathrm{A} 1, \mathrm{~A} 4, \mathrm{~A} 5, \mathrm{~A} 8$ & $f(4)$ \\
\hline
\end{tabular}

Araştırmaya katılan ebeveynlerin geribildirimlerinden 7 kategori elde edilmiştir. Bu kategoriler sırasıyla; "yönlendiren kişiler”, "hareketsizlik nedeni”, “motivasyon”, "fiziksel katkı", “zihinsel katkı", "sosyal katkı” ve "davranışsal katkı” başlıklarında oluşmuştur.

İlgili kategorilerden toplamda 20 kod elde edilmiştir. Buna göre "yönlendiren kişiler" kategorisinde, doktor yönlendirmesi, ebeveyn yönlendirmesi, arkadaş tavsiyesi kodları; "hareketsizlik nedeni" kategorisinde, televizyon izlemek, bilgisayar/telefon/tablette oyun oynamak kodları; "motivasyon" kategorisinde, istekli olmak ve mutlu olmak kodları; "fiziksel katkı" kategorisinde, vücut kompozisyonu, hareket becerileri, kaba motor beceriler, ince motor 
beceriler; "zihinsel katkı" kategorisinde, algıda artış, söyleneni anlama; "sosyal katkı" kategorisinde, genel iletişim, konuşarak iletişim, ifade şekli, vücut dilini kullanma ve "davranışsal katkı" kategorisinde, sakin olmak, özgüven ve saldırgan davranışlarda azalma kodlarına ulaşılmıştır.

Frekans değerleri incelendiğinde, katılımcıların en fazla görüş bildirdikleri kategorinin “fiziksel katkı" $f(16)$ olduğu görülmektedir. Ebeveynlerin uyarlanmış yüzme programına yönelik görüşleri önem derecesine göre sıralandığında; "fiziksel katk1, $f(16)$ ", "davranışsal katk1, $f(13)$ ", "motivasyon, $f(10)$ ", "yönlendiren kişiler, $f(10)$ ", "zihinsel katk1, $f(8)$ ", "sosyal katk1, $f(8)$ " ve "hareketsizlik nedeni, $f(7)$ " şeklinde yer almaktadır.

\section{“Yönlendiren Kişiler” Kategorisindeki Örnek Iffadeler ve Frekans Değerleri:}

Ebeveynlerin "Yönlendiren Kişiler" kategorisindeki örnek ifadeleri ve kodların frekans değerleri Tablo 3 'te sunulmuştur.

Tablo 3. "Yönlendiren Kişiler" Kategorisine Yönelik Frekans Analizi ve Örnek İfadeler

\begin{tabular}{|c|c|c|c|}
\hline Kategoriler & Kodlar & Örnek İfadeler & Katılımcılar \\
\hline \multirow{3}{*}{$\begin{array}{l}\text { Yönlendiren } \\
\text { Kişiler } \\
f(10)\end{array}$} & $\begin{array}{l}\text { Doktor } \\
\text { Yönlendirmesi }\end{array}$ & $\begin{array}{l}\text { "Doktor ve psikolog yönlendirdi. Biz de getirdik." } \\
\text { (A3) }\end{array}$ & $\mathrm{A} 3, \mathrm{~A} 10$ \\
\hline & $\begin{array}{l}\text { Ebeveyn } \\
\text { Yönlendirmesi }\end{array}$ & $\begin{array}{l}\text { “Kemiklerinin gelişmesi için getiriyorum. } \\
\text { Kemiklerinde sorun var. Kemiklerinde yamulma var. } \\
\text { Yüzmenin iyi geleceğini düşündüğüm için getirdim." } \\
\text { (A4) }\end{array}$ & $\begin{array}{l}\mathrm{A} 1, \mathrm{~A} 4, \mathrm{~A} 5 \\
\mathrm{~A} 6, \mathrm{~A} 7, \mathrm{~A} 8, \mathrm{~A} 9\end{array}$ \\
\hline & $\begin{array}{l}\text { Arkadaş } \\
\text { Tavsiyesi }\end{array}$ & $\begin{array}{l}\text { “Yüzmenin ona iyi geleceğini düşündüğüm için } \\
\text { getirdim. Araştırlyordum bir arkadaşım söyledi ben } \\
\text { hemen başvurdum.” (A2) }\end{array}$ & A2 \\
\hline
\end{tabular}

\section{“Hareketsizlik Nedeni” Kategorisine Yönelik Örnek Iffadeler ve Frekans Değerleri:}

Ebeveynlerin "Hareketsizlik Nedeni" kategorisindeki örnek ifadeleri ve kodların frekans değerleri Tablo 4'te sunulmuştur.

Tablo 4. "Hareketsizlik Nedeni” Kategorisine Yönelik Frekans Analizi ve Örnek İfadeler

\begin{tabular}{|c|c|c|c|}
\hline Kategoriler & Kodlar & Örnek İfadeler & Katılımcılar \\
\hline & Televizyon İzlemek & $\begin{array}{l}\text { "Pek hareketli değil. Televizyon izler genelde ev } \\
\text { içinde yapacă̆l fazla bir şey yok." (A6) }\end{array}$ & A2, A6 \\
\hline $\begin{array}{c}\text { Hareketsizlik } \\
\text { Nedeni } \\
f(7)\end{array}$ & $\begin{array}{l}\text { Bilgisayar/Telefon/ } \\
\text { Tablette Oyun } \\
\text { Oynamak }\end{array}$ & $\begin{array}{l}\text { “Kendini salmış bir şekilde miskin miskin oturmuş } \\
\text { bir çocuk olarak görüyorum. Başka türlü bir } \\
\text { aktiviteye katılmıyor. Ya da babasının iş yerinde } \\
\text { bilgisayarda maalesef bir aktivitesi olmuyor buraya } \\
\text { getirdiğimi kar buluyorum.” (A9) }\end{array}$ & $\begin{array}{l}\text { A2, A4, A8, } \\
\text { A9, A10 }\end{array}$ \\
\hline
\end{tabular}


“Motivasyon” Kategorisine Yönelik Örnek Ifadeler ve Frekans Değerleri:

Ebeveynlerin "Motivasyon" kategorisine yönelik örnek ifadeleri ve kodların frekans değerleri Tablo 5'te sunulmuştur.

Tablo 5. "Motivasyon” Kategorisine Yönelik Frekans Analizi ve Örnek İfadeler

\begin{tabular}{|c|c|c|c|}
\hline Kategoriler & Kodlar & Örnek İfadeler & Katılımcılar \\
\hline \multirow{2}{*}{$\begin{array}{l}\text { Motivasyon } \\
f(10)\end{array}$} & $\begin{array}{l}\text { İstekli } \\
\text { Olmak }\end{array}$ & $\begin{array}{l}\text { "Evet, istekli geliyor havuz dediğimde hemen çantasını } \\
\text { hazırlıyor "servise yetişelim bizi unutur sonra” diyor Çok } \\
\text { severek çok isteyerek geliyor istemezse inattır hayatta } \\
\text { gelmez." (A4) }\end{array}$ & $\begin{array}{l}\mathrm{A} 1, \mathrm{~A} 2, \mathrm{~A} 3 \\
\mathrm{~A} 4, \mathrm{~A} 8, \mathrm{~A} 10\end{array}$ \\
\hline & $\begin{array}{l}\text { Mutlu } \\
\text { Olmak }\end{array}$ & $\begin{array}{l}\text { “Yüzmeyi çok seviyor mutlu oluyor. Çocuk günleri bilmiyor } \\
\text { ama Çarşamba gününü biliyor nedeni de yüzme.” (A5) }\end{array}$ & $\begin{array}{l}\text { A5, A7, A9, } \\
\text { A10 }\end{array}$ \\
\hline
\end{tabular}

\section{“Fiziksel Katk”" Kategorisine Yönelik Örnek İfadeler ve Frekans Değerleri:}

Ebeveynlerin "Fiziksel Katkı" kategorisine yönelik örnek ifadeleri ve kodların frekans değerleri Tablo 6'de sunulmuştur.

Tablo 6. "Fiziksel Katkı" Kategorisine Yönelik Frekans Analizi ve Örnek İfadeler

\begin{tabular}{|c|c|c|c|}
\hline Kategoriler & Kodlar & Örnek İfadeler & Katılımcılar \\
\hline \multirow{4}{*}{$\begin{array}{c}\text { Fiziksel } \\
\text { Katkı } \\
f(16)\end{array}$} & $\begin{array}{l}\text { Vücut } \\
\text { Kompozisyonu }\end{array}$ & $\begin{array}{l}\text { "Biraz daha rahatladı. Eskisi gibi değil, göbeği çoktu } \\
\text { artık yok. Eskiden oturduğunda göbeği kat kat olurdu } \\
\text { şimdi o yok gitti, zayıfladı. Daha să̆lıklı ve vücudu daha } \\
\text { düzgün bir şekil aldl." (A7) }\end{array}$ & $\begin{array}{l}\text { A1, A3, A5, } \\
\text { A7, A9 }\end{array}$ \\
\hline & $\begin{array}{l}\text { Hareket } \\
\text { Becerileri }\end{array}$ & $\begin{array}{l}\text { “Hareketleri yavaştı daha ă̆ır gibiydi. Şimdi daha } \\
\text { iyi." (A6) }\end{array}$ & $\mathrm{A} 2, \mathrm{~A} 6$ \\
\hline & $\begin{array}{l}\text { Kaba Motor } \\
\text { Beceriler }\end{array}$ & $\begin{array}{l}\text { "Biz bir yere gidiyorduk iki adım atıyorduk pat diye } \\
\text { düşüyordu şimdi havuza getirdim düşmüyor havuz ona } \\
\text { yaradı düşmüyor yürüyor güzel yüzüyor adımlarını çok } \\
\text { güzel atıyor."(A5) }\end{array}$ & $\begin{array}{l}\text { A3, A4, A5, } \\
\text { A6, A8 }\end{array}$ \\
\hline & $\begin{array}{l}\text { İnce Motor } \\
\text { Beceriler }\end{array}$ & $\begin{array}{l}\text { ’Kalem tutamıyordu hatta 1.sınıfa götürdüm fakat } \\
\text { tekrar aldılar bu kalem tutamıyor dediler kasları } \\
\text { gelişmemiş dediler ama nasıl havuza geldi kalem } \\
\text { tutmaya başladı. Bunu çok fark ettim. Şimdi kalem } \\
\text { tutabiliyor." (A6) }\end{array}$ & $\begin{array}{l}\text { A3, A5, A6, } \\
\text { A8 }\end{array}$ \\
\hline
\end{tabular}




\section{“Zihinsel Katkı” Kategorisine Yönelik Örnek Ifadeler ve Frekans Değerleri:}

Ebeveynlerin "Zihinsel Katkı" kategorisine yönelik ifadeleri ve kodların frekans değerleri

Tablo 7'de sunulmuştur.

Tablo 7. "Zihinsel Katkı” Kategorisine Yönelik Frekans Analizi ve Örnek İfadeler

\begin{tabular}{|c|c|c|c|}
\hline Kategoriler & Kodlar & Örnek İfadeler & Katılımcılar \\
\hline \multirow{2}{*}{$\begin{array}{c}\text { Zihinsel } \\
\text { Katkı } \\
f(8)\end{array}$} & $\begin{array}{l}\text { Algıda } \\
\text { Artış }\end{array}$ & $\begin{array}{l}\text { “Yüzdüğ̈̈ için beyinsel olarak rahatladı̆̆ını düşünüyorum. } \\
\text { Mesela her türlü işi alacağı, yapacağı şeylere karşı bir } \\
\text { algılama oldu. Yüzme beynini daha fazla kullanmasını ve onu } \\
\text { zenginleştirdiğini düşünüyorum.” (A1) }\end{array}$ & $\begin{array}{l}\text { A1,A5, A7, } \\
\text { A9 }\end{array}$ \\
\hline & $\begin{array}{l}\text { Söyleneni } \\
\text { Anlama }\end{array}$ & $\begin{array}{l}\text { “İkna etmek çok zor oluyordu bazen ama şimdi öyle değil. } \\
\text { Mesela oğlum kalk bana mutfakta yardım et diyordum hani } \\
\text { biraz hareket etsin yok imkânsızdı televizyondan ayrılmazdı } \\
\text { ama şimdi daha söyleneni anlar oldu kızmıyor yani nasıl deyim } \\
\text { çok uzatmıyor.” (A10) }\end{array}$ & $\begin{array}{l}\mathrm{A} 1, \mathrm{~A} 2, \mathrm{~A} 4, \\
\mathrm{~A} 10\end{array}$ \\
\hline
\end{tabular}

“Sosyal Katk”” Kategorisine Yönelik Örnek Ífadeler ve Frekans Değerleri:

Ebeveynlerin "Sosyal Katkı" kategorisine yönelik örnek ifadeler ve kodların frekans değerleri Tablo 8'de sunulmuştur.

Tablo 8. "Sosyal Katkı" Kategorisine Yönelik Frekans Analizi ve Örnek İfadeler

\begin{tabular}{|c|c|c|c|}
\hline Kategoriler & Kodlar & Örnek İfadeler & Katılımcılar \\
\hline \multirow{4}{*}{$\begin{array}{c}\text { Sosyal } \\
\text { Katkı } \\
f(8)\end{array}$} & Genel İletişim & $\begin{array}{l}\text { "Daha iyi oldu iletişimi onu fark ettik içine biraz kapanıtı, } \\
\text { şimdi daha isteklerini söyleyebiliyor ya da hareketleri ile } \\
\text { bunu bize ifade ediyor."((A2) }\end{array}$ & $\begin{array}{l}\text { A2, A5, A6, } \\
\text { A9 }\end{array}$ \\
\hline & $\begin{array}{l}\text { Konuşarak } \\
\text { İletişim }\end{array}$ & $\begin{array}{l}\text { “Daha düzgün konuşuyor. Önceden konuştuğu zaman } \\
\text { kekeliyordu. Düzgün konuşmaya başladı ne zaman havuza } \\
\text { geldiyse değişti.(A5) }\end{array}$ & A5 \\
\hline & İfade Şekli & $\begin{array}{l}\text { “Ifadeleri daha net oldu daha anlaşılır hale geldi mesela } \\
\text { yapmayacă̆ bir şey varsa eliyle hayır diyor parmă̆ını } \\
\text { olumsuz anlamda sallyyor.” (A2) }\end{array}$ & $\mathrm{A} 2, \mathrm{~A} 3$ \\
\hline & $\begin{array}{l}\text { Vücut Dilini } \\
\text { Kullanma }\end{array}$ & $\begin{array}{l}\text { “Babasının en yakın arkadaşına gidip onu kucaklayıp neler } \\
\text { yapıyoruz filan diyor yüzmeye gelmeden önce böyle } \\
\text { yakınlaşması yoktu.” (A9) }\end{array}$ & A9 \\
\hline
\end{tabular}




\section{“Davranışsal Katkı” Kategorisine Yönelik Örnek İfadeler ve Frekans Değerleri:}

Uyarlanmış yüzme eğitiminin çocukların davranışları üzerine yaptığı katkılar hakkında ebeveynlerin örnek ifadeleri ve kodların frekans değerleri Tablo 9'de belirtilmiştir.

Tablo 9. “Davranışsal Katkı” Kategorisine Yönelik Frekans Analizi ve Örnek İfadeler

\begin{tabular}{|c|c|c|c|}
\hline Kategoriler & Kodlar & Örnek İfadeler & Katılımcılar \\
\hline \multirow{3}{*}{$\begin{array}{c}\text { Davranışsal } \\
\text { Katkı } \\
f(13)\end{array}$} & Sakin Olmak & $\begin{array}{l}\text { “...yüzmeye geldiği zaman anllyorum ki çocuk bütün } \\
\text { enerjisini döküyor mesela evde zıplıyordu filan şimdi } \\
\text { daha iyi sakinleşti iyi oldu.” (A5) }\end{array}$ & $\begin{array}{l}\mathrm{A} 1, \mathrm{~A} 4, \mathrm{~A} 5, \\
\mathrm{~A} 7, \mathrm{~A} 8, \mathrm{~A} 10\end{array}$ \\
\hline & Özgüven & $\begin{array}{l}\text { “İçine kapanıktı. Şimdi daha özgüvenli ortam içine } \\
\text { giriyor bundan herkese bahsediyor herkese anlatarak öz } \\
\text { güvenini geliştiğini gördüm Nasıl yüzdüğünü anlatıyor } \\
\text { babasına filan ben böyle yüzdüm başardım diyor.” (A6) }\end{array}$ & $\mathrm{A} 5, \mathrm{~A} 6, \mathrm{~A} 7$ \\
\hline & $\begin{array}{l}\text { Saldırgan } \\
\text { Davranışlarda } \\
\text { Azalma }\end{array}$ & $\begin{array}{l}\text { “Şu anda çok iyi okulda çok sorun yaşıyorduk tükürme } \\
\text { problemimiz vardı, saldırıyordu, vurma gibi } \\
\text { sorunlarımız vardı ama şimdi ögretmeni havuza } \\
\text { geldiğimizden beri teşekkür ediyor bunları yapmıyormuş } \\
\text { artık o yüzden çok mutluyum.” (A8) }\end{array}$ & $\begin{array}{l}\mathrm{A} 1, \mathrm{~A} 4 \\
\mathrm{~A} 5, \mathrm{~A} 8\end{array}$ \\
\hline
\end{tabular}

\section{TARTIŞMA}

$\mathrm{Bu}$ araştırmada, İstanbul Avrupa yakasındaki bir belediyeye ait havuzda 14 hafta süre ile haftada 2 gün, günde 60 dakika uyarlanmış yüzme eğitimine katılan özel gereksinimli çocukların yaşam deneyimleri, ebeveynleri tarafından dile getirilmiş ve nitel araştırma yöntemiyle ortaya konmaya çalışılmıştır. Araştırmaya katılan ebeveynlerin ifadelerinden, çocukların fiziksel, zihinsel, sosyal ve davranışsal alanlarda kazanımlar elde ettikleri anlaşılmış, bazı günlük yaşam alışkanlıklarında olumlu değişiklikler gözlendiği bulunmuştur. Ebeveynler uyarlanmış yüzme eğitimi programının çocuklarında hareket gelişimini desteklediğini söyleyerek, daha önce kalem tutamazken, ayakta dururken dahi zorlanırken, artık durumun değiştiğini, hareketlerini özgüven ve cesaretle gerçekleştirdiklerini ifade etmişlerdir.

Uyarlanmış fiziksel aktivite ve spor etkinliklerine katılan çocuklar üzerine yapılan araştırmalarda sağlıkla ilgili fiziksel uygunluk parametrelerinin geliştiği, temel motor becerilerde yetkinlik kazanıldığı, sosyal ve günlük yaşam becerilerinde özgüven geliştirdiğine dair sonuçlar elde edilmiştir (Albayrak Kuruoğlu ve Uzunçayır, 2020; Kim, Lee ve Oh, 2018; Uzunçayır, 2016; Top, 2015, Pan, 2011). Örneğin Pan'1n (2011), otizm spektrum bozukluğu olan çocuklar ve kardeşleri ile yaptığı su içi aktivite programı sonrasında, otistik çocukların kas gücü ve dayanıklılığında gelişmeler olduğu tespit edilmiştir. Top'un (2015) araştırmasında ise düzenli olarak uygulanan yüzme egzersizinin zihinsel yetersizliği olan yetişkin bireylerde fiziksel ve motor gelişimlerine olumlu katkılar sağlayarak yaşam 
kalitelerini yükselttiği sonucuna ulaşılmıştır. Bu araştırma, sosyal yapılandırmacı paradigmaya dayalı nitel araştırma yöntemiyle gerçekleştirildiğinden, literatürdeki nicel araştırmaların sonuçlarıyla direkt karşılaştırma yapılamasa da, ebeveyn ifadeleri çocuklarında belirgin ölçüde fiziksel kazanımlar gözlediklerini belirtmişlerdir.

Araştırmaya katılan ebeveynler, uyarlanmış yüzme programı öncesinde çocukların genellikle günlük yaşam rutinlerinde evde televizyon izleyerek, tablet ve telefonda oyun oynayarak zaman geçirdiklerini, bu yüzden çocuklarını olumsuz yönde etkileyen davranış problemleri yaşadıklarını ifade etmişlerdir. Uyarlanmış yüzme eğitimine katılmaya başladıktan sonra çocuklarında saldırgan davranışlar, söyleneni yapmama ve söz dinlememe gibi davranışsal sorunların sıklığının azaldığını belirtmişlerdir. Bu bulgular, Yılmaz ve diğerleri (2004) ile Lepore ve diğerlerinin (2007) çalışmalarında elde ettikleri saldırganlık, utangaçlık, kıskançlık gibi stereotipik duyguların kontrol edilerek azalması, bununla birlikte sosyal etkileşimin artması sonuçlarını destekler niteliktedir. Pan (2010), 10 haftalık su egzersizleri programından sonra otizm spektrum bozukluğu olan çocukların antisosyal davranışlarında azalma ve yüzme becerilerinde önemli bir artış olduğu sonucuna ulaşmıştır. Bu araştırmaya katılan ebeveynler, 14 hafta süren eğitim programının, çocuklarında konuşmaya başlama, iletişim kurma, isteklerini ifade edebilme ve vücut dilini kullanma davranışları üzerine de olumlu etkisi olduğunu önemle belirtmişlerdir. Bu bulgu, Albayrak Kuruoğlu ve Uzunçayır'ın (2020) su içi aktivitelerin zihinsel yetersizliği olan çocuklarda sosyal beceriler üzerine etkisini araştıran çalışmalarının sonuçlarını destekler niteliktedir. Bella'nın (2019) otizm spektrum bozukluğu olan çocuklarla ilgili araştırmasında da, su içi egzersizlerin özellikle ilişsi başlatma ve sürdürme becerilerine olumlu etkisinden bahsedilmektedir. Uzunçayır (2016), 14 haftalık özel gereksinimli çocukların su içi aktivitelerine katılımının sosyal beceri gelişimini desteklediğini ve yaşam kalitesini arttırdığını belirtmiştir.

Bu araştırmada suyun çocukların dünyayı algılamasında artışa neden olduğu, sakinleştirdiği ve özgüven duygusu geliştirdiği ebeveynleri tarafından belirtilmiştir. Fragala-Pinkham, Haley ve O’Neil (2011) otizm spektrum bozukluğu olan çocuklar için 14 hafta boyunca düzenlenen su içi egzersiz programının, ebeveyn geri bildirimlerinde ödevlerini yaparken daha dikkatli ve odaklandıklarını belirtmişlerdir. Fragala-Pinkham ve diğerlerinin (2011) araştırmasına katılan ebeveynler, çocuklarının göz teması kurma, akranları ve eğitmenleri ile iletişime geçme, sınıf kurallarına uyma ve benlik saygısı üzerinde de olumlu bir etkisi olduğunu ifade etmişlerdir. İlhan'ın (2009) araştırmasında; özel gereksinimli çocuklarını sportif etkinliklere yönlendiren ebeveynlerin, çocuklarının tüm gelişim yönlerine etkisi konusunda olumlu geribildirimler vererek, en çok yapılması istenen spor branşının yüzme olduğunu belirtmişlerdir.

Havuz ortamında gerçekleştirilen uyarlanmış yüzme ve diğer su içi aktiviteler, özel gereksinimli çocuklar için eğlenceli ve her zaman yaptıkları yaşam davranışlarından farklı olanaklar sunmaktadır. Bu araştırmanın en çarpıcı sonuçlarından biri, literatürde pek de rastlanmayan "zihinsel kazanımlar” temasının ortaya çıkmasıdır. Frekans değeri 8 olarak bulunan "zihinsel kazanımlar" kategorisinde, ebeveynler çocuklarında alg1 düzeyinin ve zihinsel faaliyetlerinin geliştiğinden, böylelikle sosyal ilişkilerinin rahatlayarak, kendilerini 
daha rahat ifade edebildiklerinden bahsetmişlerdir. Araştırmadan elde edilen diğer bir çarpıcı sonuç ise, "motivasyon" kategorisinde ulaşılan havuza istekle ve mutlulukla gelmeleri, üç buçuk ay gibi uzun süreli bir programa devam etmeye motive olmalarıdır. Bu kategoride görüş bildiren hafif derece zihinsel yeterlilik tanısı olan çocuğun "A5" kodlu ebeveyni, "çocuk günleri bilmiyor ama Çarşamba gününü biliyor, nedeni de yüzme." diyerek, aslında bu türden fiziksel aktivite ve uyarlanmış spor eğitimlerinin zihinsel çocuklar üzerinde zihinsel farkındalığa etki ettiğinin bir göstergesi olarak düşünülebilir. Yine de zihinsel alana yönelik bu değişimin Albayrak Kuruoğlu ve Uzunçayır (2020), Bella (2019) ve Yılmaz ve diğerlerinin de (2004) belirttiği gibi "kalıcı" olup olmadığı bilinmemektedir. Bu nedenle, özel gereksinimli çocuklara yönelik uyarlanmış fiziksel aktivite ve spor programları uzun süreli olarak bu çocukların hayatlarında yer almalıdır.

\section{SONUÇ ve ÖNERILER}

Özel gereksinimli çocuklara yönelik ister rekreasyon amaçl1, ister özel sporcu yetiştirme amaçlı olsun, optimal sıklık, şiddet, süre ve kapsamda programlanan uyarlanmış aktivitelerin, bu çocukların fiziksel, zihinsel, sosyal ve davranışsal kazanımlara ulaşılacağı düşünülmektedir. Özel gereksinimli çocukların daha fazla uyarlanmış fiziksel aktivite ve spor eğitimlerine katılabilmesi için gerekli koşullar oluşturulmalı, yerel yönetimler bu eğitimleri ücretsiz düzenlemeye devam etmeli ve tüm Türkiye'de yaygınlaştırılmalıdır.

Yayın Etiği: $\mathrm{Bu}$ çalışmanın hazırlanma ve yazım sürecinde "Yükseköğretim Kurumları Bilimsel Araştırma ve Yayın Etiği Yönergesi” kapsamında bilimsel, etik ve alıntı kurallarına uyulmuş olup; toplanan veriler üzerinde herhangi bir tahrifat yapılmamış ve bu çalışma herhangi başka bir akademik yayın ortamına değerlendirme için gönderilmemiştir.

\section{KAYNAKLAR}

Albayrak Kuruoğlu, M. Y. ve Uzunçayır, D. (2020). Zihinsel yetersizliği olan çocuklarda uyarlanmış su içi egzersizlerin sosyal beceriler üzerine etkisi. Gazi Beden Ĕ̆itimi ve Spor Bilimleri Dergisi, 25(2), 117126.

Albert P. T. (2010). Alternative exercise may be attractive to more individuals. Home Health Care Managment Practice, 22, 301-304.

Bella, M. (2019). Do aquatic activities boost social skills for children with autism spectrum disorders? Journal of Pedagogy, 2, 151-171. https://doi.org/10.26755/RevPed/2019.2/151.

Casey, A. F., Rasmussen. R., Mackenzie, S. J. ve Glenn. J. (2010). Dual- energy x-ray absorptiometry to measure the influence of a 16 week community-based swim training program on body fat in children and adolescents with intellectual disabilities. Archives Physical Medicine and Rehabilitation, 91, 10641069.

Creswell, J.W. (2013) Qualitative Methods. In Research Design: Qualitative, Quantitative, and Mixed Methods Approaches, edited by J.W. Creswell, 231-263. 4th ed. Thousand Oaks: SAGE Publications. 
Albayrak Kuruoğlu, M.Y. ve Uzunçayır, D. (2020). Uyarlanmış yüzme eğitiminin, özel gereksinimli çocuklar üzerindeki etkilerinin ebeyenleri tarafindan seslendirilmesi. Ulusal Spor Bilimleri Dergisi, 4(2), 00-00.

Çamlıüney, A. F. (2001). Down sendromlu çocukların gelişsiminde yüzme sporu ile beden eğitimi uygulamalarının karşılaş̧tıılması. Marmara Üniversitesi Sağlık Bilimleri Enstitüsü, İstanbul.

Fragala-Pinkham, M. A., O’Neil, M. E.ve Haley, S. M. (2010). Summative evalution of a pilot aquatic exercise program for children with disabilities. Disability and Health Journal, 3,162-170.

Fragala-Pinkham, M. A., Haley, S. M. ve O'Neil, M. E. (2011). Group swimming and aquatic exercise programme for children with autism spectrum disorder: A Pilot study. Developmental Neurorehabilitation, 14(4), 220-241. https://doi:10.3109/17518423.2011.575438.

Getz, M., Hutzler, Y. ve Vermeer, A. (2007). The effects of aquatic intervention on perceived physical competence and social acceptance in children with cerebral palsy. European Journal of Special Needs Education, 22(2), 217-228.

İlhan, L. (2009). Zihinsel engelli çocuğu olan anne-babaların çocuklarının özel eğitimleri sürecinde beden eğitimi ve spor etkinliklerine yaklaşımlarının değerlendirilmesi. Niğde Üniversitesi Beden Eğitimi ve Spor Bilimleri Dergisi, 3(1), 8-48.

Kim, K. H., Lee, B. A. ve Oh, D. J. (2018). Effects of aquatic exercise on health-related physical fitness, blood fat, and immune functions of children with disabilities. Journal of Exercise Rehabilitation, 14(2), 289293.

Lawson, L., M, Foster, L. ve Harrington, M. (2014). Effects of a swim program for children with autism spectrum disorder on skills, interest, and participation in swimming. American Journal Recreation Therapy, 13, $17-27$.

Lepore, M., Gayle, G. W. ve Stevens, S. F. (2007). Adapted aquatic programs: A Professional guide. Champaign, IL: Human Kinetics.

Martin, K. (1983). Therapeutic pool activities for young children in a community facility. Physical Occupational Therapy in Pediatrics, 31, 59-74.

Merriam, S. B. (2013). Nitel Araştırma Desen ve Uygulama İçin Bir Rehber (Çev. S. Turan). Ankara: Nobel Akademik Yayıncilık.

Miller, N. E., (2005). An aquatic occupational therapy program for children with physical, developmental, and psychosocial disabilities, University of North Dakota. https://commons.und.edu/ot-grad/138

Pan, C. Y. (2010). Effects of water exercise swimming program on aquatic skills and social behaviors in children with autism spectrum disorders. Autism: The International Journal of Research and Practice, 14(1), 928.

Pan, C.Y. (2011). The efficacy of an aquatic program on physical fitness and aquatic skills in children with and without autism spectrum disorders. Research in Autism Spectrum Disorders, 5, 657-665.

Patton, M. Q. (2014). Nitel Araştırma ve Değerlendirme Yöntemleri (Çev. M. Bütün ve S. B. Demir). Ankara: Pegem Akademi.

Strauss, A. ve Corbin, J. M. (1990). Basics of qualitative research: Grounded theory procedures and techniques. Sage Publications, Inc.

Top, E. (2015). 12 haftalı y yüzme egzersizinin zihinsel engelli bireylerin fiziksel uygunluk düzeyleri ne etkisinin incelenmesi. Dumlupınar Üniversitesi Sağlık Bilimleri Enstitüsü, Kütahya.

Türnüklü, D. (2000). Eğitim bilim araştırmalarında etkin olarak kullanılabilecek nitel bir araştırma tekniği: Görüssme. Kuram ve Uygulamada Eğitim Yönetimi, 24(24), 543-559.

Uzunçayır, D. (2016). Özel gereksinimli bireylerde su içi aktivitelerin sosyal beceri ve yaşam kalitesine etkisi. Gedik Üniversitesi Sağlık Bilimleri Enstitüsü, İstanbul. 
Yıldırım, A. ve Şimşek, H. (2016). Sosyal Bilimlerde Nitel Araștırma Yöntemleri, 10. Baskı. Ankara: Seçkin Yayınlar1.

Y1lmaz, İ., Konukman, F., Birkan, B. ve Yanardağ, M. (2010). The effects of most to least prompting on teaching simple progression swimming skill for children with autism. Education and Training in Autism and Developmental Disabilities, 45, 440-448.

Yılmaz, İ., Yanardağ, M., Birkan, B. ve Bumin, G. (2004). Effects of swimming training on physical fitness and water orientation in autism, Pediatrics International, 46, 624-626.

Bu eser Creative Commons Atıf-GayriTicari 4.0 Uluslararası Lisansı ile lisanslanmışır. 